九州大学学術情報リポジトリ

Kyushu University Institutional Repository

\title{
Utilization of Xylose as an Alternative Carbon Source for Nisin Z Production by Lactococcus lact is $10-1$
}

Chinachoti, Noppawan

Matsusaki, Hiromi

Laboratory of Microbial Technology, Department of Food Science and Technology, Faculty of Agriculture, Kyushu University

Sonomoto, Kenj i

Laboratory of Microbial Technology, Department of Food Science and Technology, Faculty of Agriculture, Kyushu University

Ishizaki, Ayaaki

Laboratory of Microbial Technology, Department of Food Science and Technology, Faculty of Agriculture, Kyushu University

https://doi.org/10.5109/24204

出版情報：九州大学大学院農学研究院紀要. 42 (1/2)，pp.171-181，1997-12. Kyushu University バージョン：

権利関係: 


\title{
Utilization of Xylose as an Alternative Carbon Source for Nisin Z Production by Lactococcus lactis IO-1
}

\author{
Noppawan Chinachoti, Hiromi Matsusaki, Kenji Sonomoto \\ and Ayaaki Ishizaki \\ Laboratory of Microbial Technology, Department of Food Science and Technology, \\ Faculty of Agriculture, Kyushu University, \\ 6-10-1 Hakozaki, Higashi-ku, Fukuoka 812-81, Japan \\ (Received July 30, 1997 and accepted August 25, 1997)
}

\begin{abstract}
Lactococcus lactis IO-1 was able to use xylose as a carbon source for nisin Z production, whose yield was superior to that made with glucose under the same fermentation conditions. Nisin Z production was affected by several environmental factors, such as $\mathrm{pH}$, temperature, initial xylose concentration and the addition of a cation. In view of possible future use, these factors have to be considered for designing the production process. From this study, the optimal condition for nisin $\mathrm{Z}$ production was obtained with $4 \%$ xylose at $\mathrm{pH} 6.0$ and $37^{\circ} \mathrm{C}$. Addition of $0.1 \mathrm{M} \mathrm{CaCl}_{2}$ increased nisin $\mathrm{Z}$ production specifically, but not cell growth and acid production, which resulted in the maximum nisin $Z$ activity of about 1.5 times that without $\mathrm{CaCl}_{2}$.
\end{abstract}

\section{INTRODUCTION}

As the world population continuously increases and new technologies are being developed, many natural resources are daily decreased. To prevent the problem of resource shortage, the effective utilization of natural resources should be studied. Reuse of waste has been introduced to human life. The main portion of waste generally comes from the agricultural field, and many researchers are trying to utilize it. Agricultural waste is composed of many kinds of polysaccharides, such as cellulose, hemicellulose and lignin. Xylose is one kind of sugar which is obtained after the hydrolysis of these waste products. Ishizaki et al. (1992b, 1993, 1995b) reported the utilization of xylose for Llactate production by lactic acid bacteria. Lactococcus lactis IO-1, a lactic acid bacterium that was isolated in our laboratory, produces mainly L-lactic acid from many kinds of sugar, including xylose (Ishizaki and Ohta, 1989). Furthermore, L. lactis IO-1 was found to produce a peptide antibiotic which was identified as nisin $\mathrm{Z}$, a natural nisin variant bacteriocin (Ishizaki et al., 1990; Ishizaki et al., 1992a; Matsusaki et al., 1996b). Nisin was approved as a food preservative (Delves-Brounghton, 1990) because of its high effectiveness against several strains of Gram-positive food pathogen such as Bacillus (de Vuyst and Vandamme, 1994), Clostridium (de Vuyst and Vandamme, 1994), and Listeria (Winkowski et al., 1994; Benkerroum and Sandine, 1988).

Recently the influence of several parameters on nisin $Z$ production from glucose fermentation was reported focussing on the enhancement of nisin $Z$ productivity, as a result, a maximal nisin $\mathrm{Z}$ production was obtained from $4 \%$ glucose fermentation supplemented with $0.1 \mathrm{M} \mathrm{CaCl}_{2}$ (Matsusaki et al., 1996a). The major effect of calcium ion 
on nisin-producing cellis was reported on nisin maturation and immunity. Calcium ion was believed to play a role in the integrity of the lipid membrane of the producing strain (de Vuyst and Vandamme, 1993). Uptake of calcium ion was linked to nisin inactivation and thus suggested that nisin was bound to nisin-producing cells in the form of a calcium complex (de Vuyst and Vandamme, 1994). Calcium ion binding sites are probably present in Nis P peptidase, which cleaves the precursor nisin, followed by the liberation of mature nisin (Matsusaki et al., 1996a).

Natural rubber serum powder (NRSP) is the spray-dried product of the serum obtained during the process of separating natural rubber latex. Because the serum containing many kinds of amino acids, peptides, inorganic salts, etc. causes environmental pollution with its putrid and foul smell, the treatment of the serum has become a serious problem in natural rubber-producing countries. In our laboratory, it has been found that NRSP can be used as a nutritional source for many kinds of microorganisms. Tripetchkul et al. (1992) reported the use of NRSP as a nutritional source in ethanol production by Zymomonas mobilis. They stated that the yeast extract in the medium can be replaced by NRSP and mieki (soybean protein hydrolysate). Ishizaki (1995a) and Oiki et al. (1996) reported the growth-promoting effect of NRSP on bifidobacterium, consequently with enhancing metabolite production and yields. Recently lactic acid fermentation with xylose by L. lactis IO-1 was stimulated by NRSP (unpublished data).

For the efficient utilization of natural resources and as an alternative trial for agricultural waste treatment, xylose and NRSP are expected to be potentially an alternative carbon source and growth promoter for nisin $\mathrm{Z}$ production, respectively. Until now, no information on bacteriocin production from agricultural waste or its hydrolysate has been reported. The objective of this study is to optimize conditions for nisin $\mathrm{Z}$ production using xylose as a carbon source and to determine the effect of additives such as NRSP and calcium chloride.

\section{MATERIALS AND METHODS}

\section{Microorganism and media}

Lactococcus lactis IO-1 (JCM 7638) was maintained in $30 \%$ glycerol at $-80^{\circ} \mathrm{C}$. The culture was refreshed in $10 \mathrm{ml}$ TGC medium without glucose (Difco Laboratories, Detroit, MI, USA) at $37^{\circ} \mathrm{C}$ for $18 \mathrm{~h}$ and was propagated in CM medium which consisted of $0.5 \%$ polypeptone (Nihon Seiyaku Co., Ltd., Tokyo, Japan), 0.5\% yeast extract (Difco Laboratories, Detroit, MI, USA) and $0.5 \% \mathrm{NaCl}$. Xylose was added in preculture medium in the amount of $1 \% \mathrm{w} / \mathrm{v}$. Preculture was incubated at $37^{\circ} \mathrm{C}$ for $3 \mathrm{~h}$ as an inoculum of the main culture.

\section{Fermentation in reciprocated-flask}

Experiments were performed in 300-ml Erlenmeyer flasks with 100-ml working volume. Calcium carbonate was added to the CM medium containing the indicated sugar about half the sugar concentration to prevent rapid decrease in $\mathrm{pH}$. The inoculated volume was $5 \%$. The main culture was incubated at a speed of 100 strokes/min. 


\section{pH-controlled fermentation}

A 1-l fermenter containing $300 \mathrm{ml} \mathrm{CM}$ medium was added with $4 \%$ xylose. The fermenter was operated at $37^{\circ} \mathrm{C}$ with an agitation speed of $400 \mathrm{rpm}$. The $\mathrm{pH}$ of the fermentation broth was maintained with $3 \mathrm{~N} \mathrm{NaOH}$.

\section{Analytical methods}

The absorption of light at $562 \mathrm{~nm}$ was measured and was converted to dry cell weight (DCW). Xylose, lactate and acetate were analyzed by Shimadzu high-performance liquid chromatography (HPLC) with Aminex ion-exclusion column HPX-87H (Bio-Rad Laboratories, Inc., Hercules, CA, USA). Nisin Z was determined by reverse-phase HPLC with Shodex Asahipak ODP 50-6E column (Showa Denko Co., Ltd., Tokyo, Japan) (Matsusaki et al., 1996b). One unit of nisin Z activity is defined as an arbitary unit (AU) of activity that is equivalent to the activity of $1 \mu \mathrm{g}$ of commercial nisin (ICN Biomedicals, Inc., Costa Mesa, CA, USA; activity, $1000 \mathrm{IU} / \mathrm{mg}$-solid; nisin content, 2.5\%). Thus one AU is equivalent to one IU.

\section{RESULTS}

\section{The possibility of producing nisin $\mathrm{Z}$ from xylose}

L. lactis 1O-1 grew well at $37^{\circ} \mathrm{C}$ (Ishizaki et al., 1990), and the highest nisin Z was produced at $30^{\circ} \mathrm{C}$ when glucose was used as the carbon source (Matsusaki et al., 1996b). To study the possibility of nisin $\mathrm{Z}$ production from xylose, L. lactis IO-1 was grown in $300-\mathrm{ml}$ Erlenmeyer flask containing $100 \mathrm{ml} \mathrm{CM}$ medium, $1 \%$ xylose and $0.5 \% \mathrm{CaCO}_{3}$. The cultures were incubated at $30^{\circ} \mathrm{C}$ and $37^{\circ} \mathrm{C}$ at a speed of 100 strokes/min. Nisin Z was first detected early during the exponential growth phase and showed the maximum level during the mid-exponential phase, which indicates that bacteriocin displays primary metabolite kinetics (de Vuyst and Vandamme, 1994). Maximal nisin Z activity and yields of nisin $\mathrm{Z}$ and lactate production in each xylose fermentation were compared with those in glucose fermentation which was incubated at $30^{\circ} \mathrm{C}$ (Table 1). Using xylose as a carbon

Table 1. Comparison of maximum nisin $\mathrm{Z}$ activity and yields of nisin $\mathrm{Z}$ and lactate production under different conditions

\begin{tabular}{|c|c|c|c|c|c|}
\hline \multirow{2}{*}{$\begin{array}{l}\text { Condition } \\
\text { Glucose } 1 \% \\
\text { at } 30^{\circ} \mathrm{C}\end{array}$} & \multirow{2}{*}{$\frac{\begin{array}{c}\text { Maximum nisin Z } \\
(\mathrm{AU} / \mathrm{ml})\end{array}}{737}$} & \multicolumn{2}{|c|}{$\begin{array}{c}\text { Nisin } \mathrm{Z} \text { yield } \\
\left(\times 10^{5} \mathrm{AU} / \mathrm{g}-\mathrm{sugar}\right)\left(\times 10^{\mathrm{f}} \mathrm{AU} / \mathrm{g}-\mathrm{DCW}\right)\end{array}$} & \multicolumn{2}{|c|}{$\begin{array}{c}\text { Lactate yield } \\
(\mathrm{g} / \mathrm{g}-\mathrm{sugar})(\mathrm{g} / \mathrm{g}-\mathrm{DCW})\end{array}$} \\
\hline & & 0.750 & 0.860 & 0.960 & 13.4 \\
\hline $\begin{array}{l}\text { Xylose } 1 \% \\
\text { at } 30^{\circ} \mathrm{C}\end{array}$ & 810 & 0.930 & 1.11 & 0.140 & 1.67 \\
\hline $\begin{array}{l}\text { Xylose } 1 \% \\
\text { at } 37^{\circ} \mathrm{C}\end{array}$ & 744 & 1.13 & 1.13 & 0.120 & 1.63 \\
\hline
\end{tabular}

DCW, dry cell weight 
source, nisin $\mathrm{Z}$ was produced at both incubating temperatures. In $1 \%$ glucose fermentation, $L$. lactis IO-1 grew faster than in $1 \%$ xylose fermentation. The specific growth rate of IO-1 cells in glucose fermentation was about $0.67 \mathrm{~h}^{-1}$, whereas that in xylose fermentation was about $0.10 \mathrm{~h}^{-1}$ at both temperatures. The maximal amounts of nisin $\mathrm{Z}$ were obtained at $12 \mathrm{~h}$ in glucose fermentation at $30^{\circ} \mathrm{C}$, and at $15 \mathrm{~h}$ and $18 \mathrm{~h}$ in xylose fermentation at $37^{\circ} \mathrm{C}$ and $30^{\circ} \mathrm{C}$, respectively. It is interesting that lactate yields from xylose fermentations were much lower than those in glucose fermentation. This should be an advantage for nisin Z production from xylose fermentation, as lactate inhibits the growth of the producer strain (Ishizaki et al., 1993). The rate of xylose consumption was lower than that of glucose consumption, which resulted in higher nisin $\mathrm{Z}$ yield based on carbon source consumption.

\section{Effect of initial xylose concentration on nisin $\mathrm{Z}$ production}

In order to prolong the exponential phase which might result in the increase in cell density and concomitantly nisin production, flask-based cultivations were carried out at $37^{\circ} \mathrm{C}$ with increasing initial xylose concentration of 10 to $70 \mathrm{~g} / \mathrm{l}$. Calcium carbonate was added to each flask at half the xylose concentration. Cell growth, lactate and nisin $\mathrm{Z}$ production after $24 \mathrm{~h}$ of incubation are shown in Fig. 1. Lactate produced increased with an increase in xylose concentration. The cell formation gradually decreased when xylose concentration was increased higher than $20 \mathrm{~g} / l$. On the other hand, nisin $Z$ activity increased with increasing xylose concentration over the range of 10 to $40 \mathrm{~g} / \mathrm{l}$. The highest value was achieved with $40 \mathrm{~g} / l$ xylose in the amount of $942 \mathrm{AU} / \mathrm{ml}$. Above $40 \mathrm{~g} / \mathrm{l}$ of xylose, growth and nisin $\mathrm{Z}$ production were limited by low $\mathrm{pH}$, although xylose remained sufficiently available.

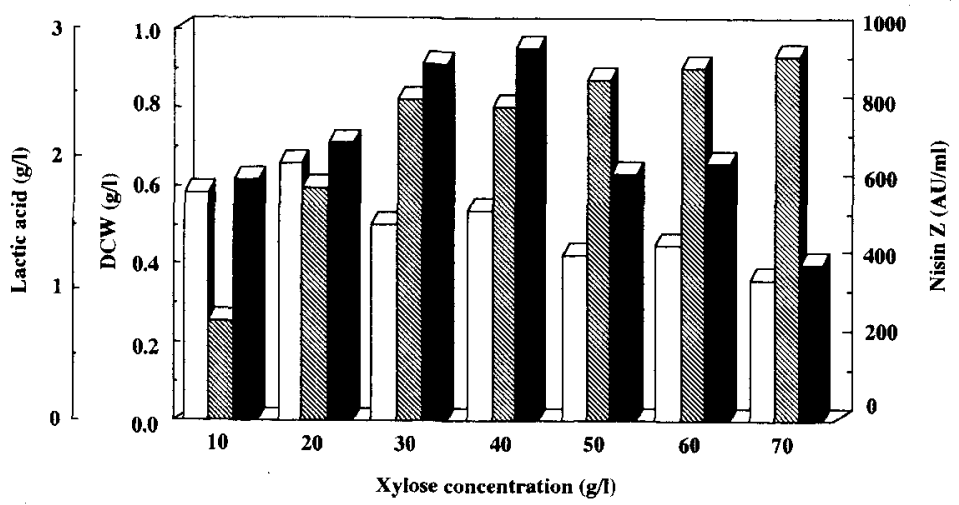

Fig. 1. Cell formation, lactate formation and nisin $\mathrm{Z}$ production of Lactococcus lactis IO-1 with different xylose concentrations. The cultivation was carried out at $37^{\circ} \mathrm{C}$ and 100 strokes/min for $24 \mathrm{~h}$.

Symbols: Cell growth $(\square)$, lactate $(\mathbb{\mathbb { N }})$, nisin $\mathrm{Z}$ 


\section{Effect of incubating temperature}

Bacteriocin production was influenced by several environmental parameters of the fermentation, including $\mathrm{pH}$ and temperature (de Vuyst and Vandamme, 1994; Biswas et al., 1991; Parente et al., 1994). To study the effect of the temperature, L. lactis IO-1 was cultivated in $300-\mathrm{ml}$ Erlenmeyer flasks containing $40 \mathrm{~g} / l$ xylose at different temperatures. Cell growth, lactate and nisin $\mathrm{Z}$ production after $24 \mathrm{~h}$ of incubation are shown in Fig. 2. The growth was not good at low temperature $\left(20\right.$ and $\left.25^{\circ} \mathrm{C}\right)$ and at $40^{\circ} \mathrm{C}$. The trends of lactate and nisin $\mathrm{Z}$ production corresponded with cell growth. No nisin $\mathrm{Z}$ was produced at $20^{\circ} \mathrm{C}$. The highest nisin $\mathrm{Z}$ activity was detected at $37^{\circ} \mathrm{C}$ at $988 \mathrm{AU} / \mathrm{ml}$. The optimal temperature for nisin and biomass production was $37^{\circ} \mathrm{C}$. From these results, nisin $\mathrm{Z}$ was proportionally related to biomass, as de Vuyst and Vandamme (1992) stated that achieving a high biomass may be a prerequisite for high nisin production.

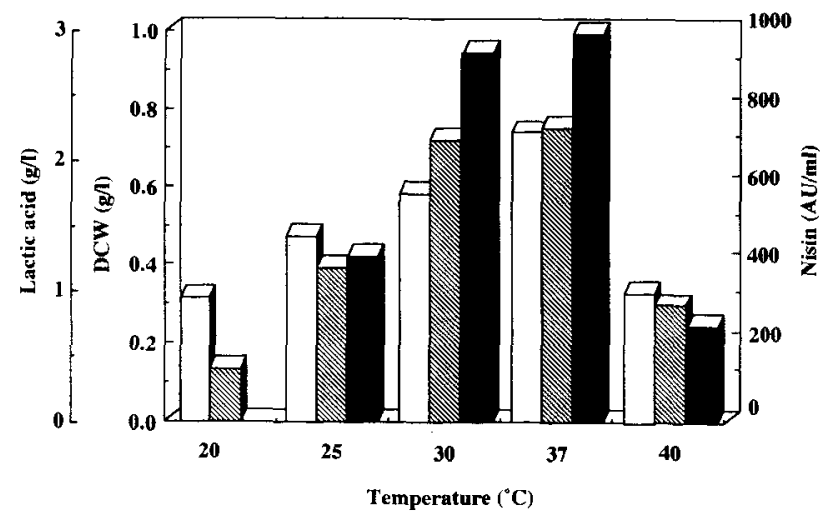

Fig. 2. Effect of temperature on growth, lactate production and nisin Z production of Lactococcus lactis IO-1. The cultivation was performed at 100 strokes/min with $4 \%$ xylose and $2 \% \mathrm{CaCO}_{3}$. Samples were withdrawn after $24 \mathrm{~h}$ of incubation.

Symbols: Cell growth ( $\square$ ), lactate (四), nisin Z (

\section{Effect of natural rubber serum powder}

There were some reports on the enhancing effect of natural rubber serum powder (NRSP) on the production of ethanol and the growth of bifidobacterium (Tripetchkul et al., 1992; Ishizaki, 1995a; Oiki et al., 1996). NRSP enhanced not only the growth of bifidobacterium, but also the metabolite production and its yield. NRSP was examined to learn whether this powder promotes nisin $\mathrm{Z}$ production. As shown in Fig. 3a, the growth of IO-1 cells with $1.5 \%$ NRSP was greater than that without NRSP. Nisin Z production is shown in Fig. 3b. When 1.5\% NRSP was added, nisin $Z$ production was not affected, whereas lactate production was increased about 3 times that of the control (Fig. 3c). The lactate formation rate increased from $0.12 \mathrm{~g} \cdot \ell^{-1} \cdot \mathrm{h}^{-1}$ without NRSP to $0.31 \mathrm{~g} \cdot \ell^{-1} \cdot \mathrm{h}^{-1}$ with 

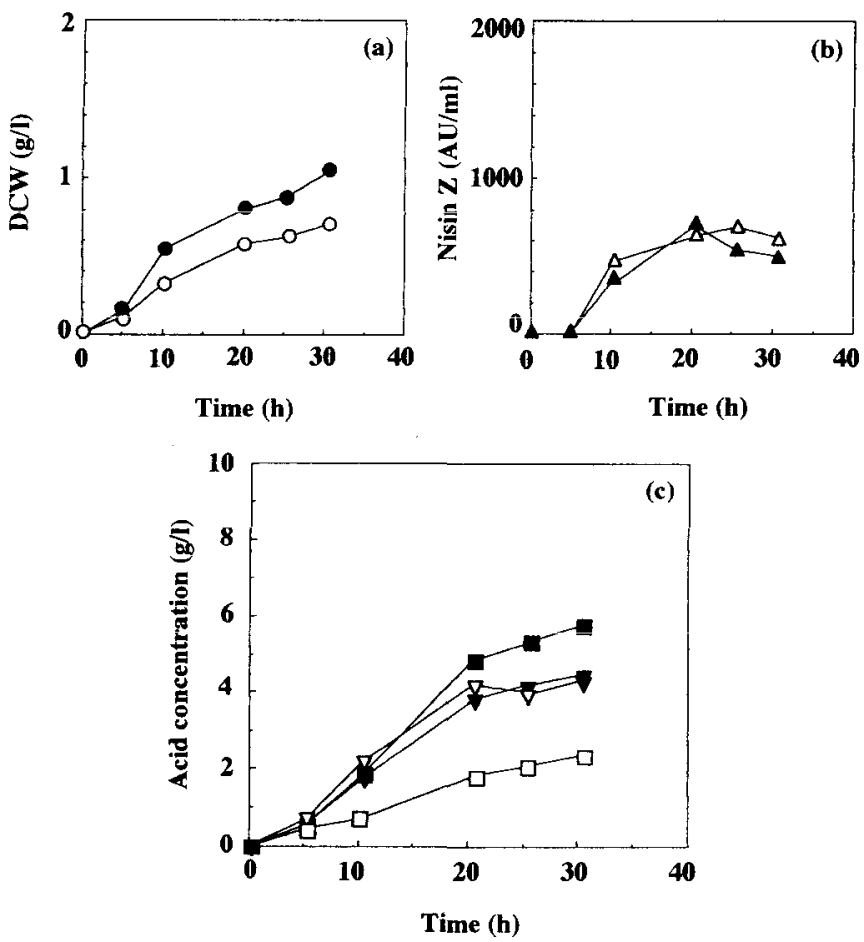

Fig. 3. Effect of NRSP on cell mass (a), nisin Z production (b), and lactate and acetate production (c). The cultivation was performed at $37^{\circ} \mathrm{C}$ and 100 strokes $/ \mathrm{min}$ with $4 \%$ xylose and $2 \%$ $\mathrm{CaCO}_{3}$.

Symbols: Control (open symbols), with 1.5\% NRSP (closed symbols) Cell growth $(\mathbf{O}, \bigcirc)$, nisin $\mathrm{Z}(\mathbf{\Delta}, \triangle)$, lactate $(\mathbf{\square}, \square)$, acetate $(\boldsymbol{\nabla}, \nabla)$

$1.5 \%$ NRSP. To confirm the effect of NRSP on nisin $\mathrm{Z}$ production, pH-controlled fermentation was carried out in the presence of $1.5 \%$ NRSP. NRSP affected only the stimulation of lactate production, whereas cell growth, acetic acid and nisin Z production were not affected (Fig. 4).

\section{Effect of cation}

From the previous research (Matsusaki et al., 1996a) the production of nisin Z from glucose was increased when $\mathrm{CaCl}_{2}$ was added. The effect of calcium ion and other cations on nisin $\mathrm{Z}$ production with xylose was studied. The cultures were cultivated with $0.1 \mathrm{M}$ of

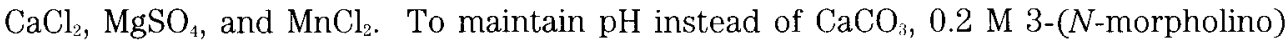
propanesulfonic acid (MOPS) was used as a buffer. The results are shown in Fig. 5. No nisin was produced from the fermentation with $0.1 \mathrm{M} \mathrm{MnCl}_{2}$. Nisin $Z$ production was increased $11 \%$ and $40 \%$ with $0.1 \mathrm{M} \mathrm{MgSO}_{4}$ and $0.1 \mathrm{M} \mathrm{CaCl}_{2}$, respectively. In flask-based fermentation with MOPS, the cell growth and nisin Z production were lower than those with $\mathrm{CaCO}_{3}$. Application of $50 \mathrm{mM}$ potassium phosphate buffer instead of MOPS also resulted in low growth rate and led to low nisin $\mathrm{Z}$ production. 

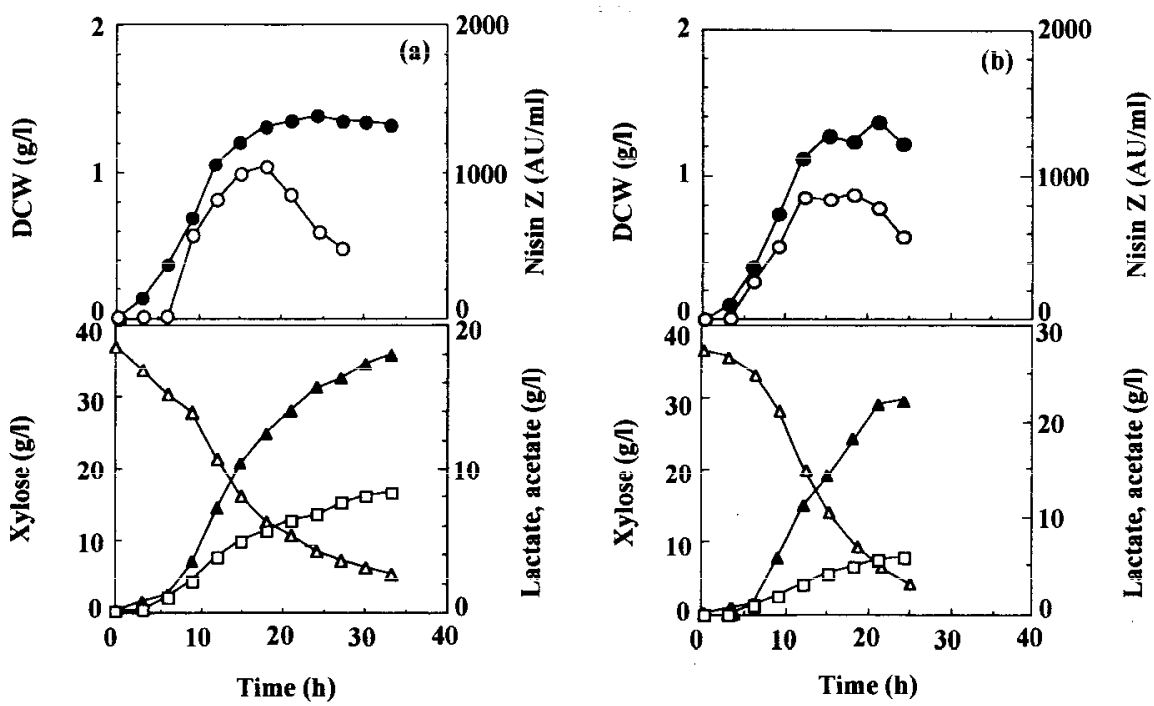

Fig. 4. Effect of NRSP on nisin $\mathrm{Z}$ production in $\mathrm{pH}$-controlled fermentation. The cultivation was carried out at $37^{\circ} \mathrm{C}$ and $\mathrm{pH} 6.0$ with $4 \%$ xylose and without NRSP (a) and with $1.5 \%$ NRSP (b)

Symbols: Cell growth $(\mathbf{O})$, nisin $Z(\bigcirc)$, lactate $(\boldsymbol{A})$, acetate $(\square)$, xylose $(\triangle)$

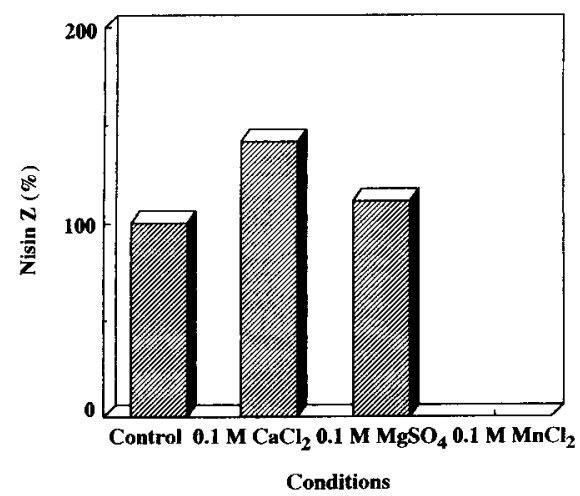

Fig. 5. Effect of cation on nisin $\mathrm{Z}$ production by Lactococcus lactis IO-1. The cultivation was performed at $37^{\circ} \mathrm{C}$ and 100 strokes/min for $24 \mathrm{~h}$ with $4 \%$ xylose and $0.2 \mathrm{M}$ MOPS. Nisin $Z$ production in control, that is without any cation, was expreesd as $100 \%$.

\section{Effect of $\mathrm{pH}$ in pH-controlled fermentation}

To determine the optimal conditions for bacteriocin production, $\mathrm{pH}$ is one of the important factors (Biswas et al., 1991; Parente et al., 1994). The cultures were grown in 

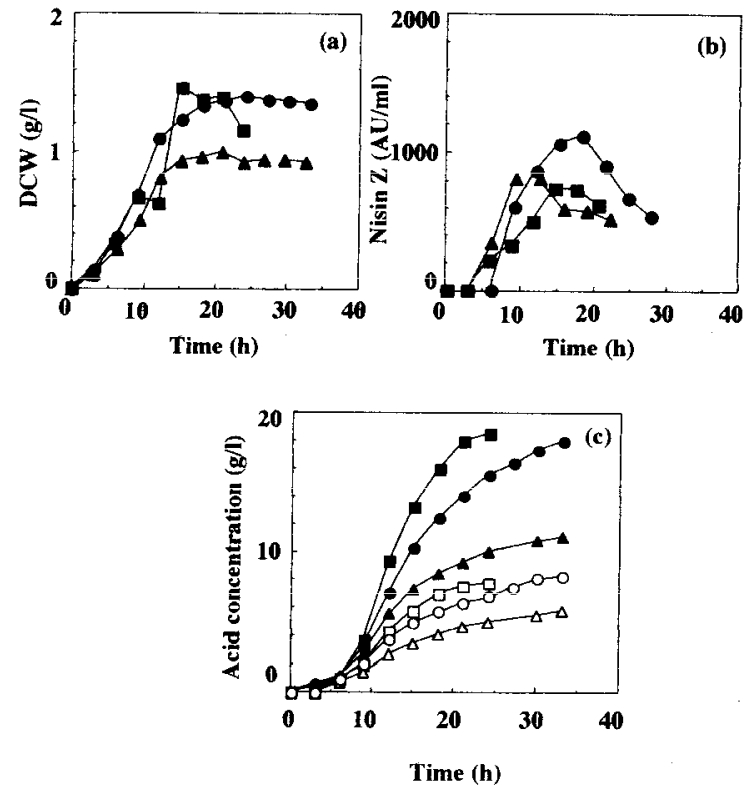

Fig. 6. Effect of $\mathrm{pH}$ on cell growth (a), nisin $\mathrm{Z}$ production (b), and lactate and acetate production (c) of Lactococcus lactis 10-1. The cultivation was carried out in 1-L jar fermenter with $4 \%$ xylose at $37^{\circ} \mathrm{C}$. The indicated $\mathrm{pH}$ was maintained with $3 \mathrm{~N} \mathrm{NaOH}$.

Symbols: pH $5.5(\mathbf{\Delta})$, pH 6.0

In Fig. 6c, acetate (open symbols), lactate (closed symbols)

a pH-controlled fermenter at $\mathrm{pH} 5.5,6.0$, and 6.5 (Fig. 6). Cell formation at $\mathrm{pH} 5.5$ was lower than that at $\mathrm{pH} 6.0$ and 6.5. Consequently, lactate production and nisin biosynthesis were poor at $\mathrm{pH} 5.5$. Lactate was rapidly produced with $\mathrm{pH}$ controlled at 6.5 , while the highest nisin production was achieved from the fermentation with $\mathrm{pH}$ controlled at 6.0. The optimal $\mathrm{pH}$ of nisin production with xylose $(\mathrm{pH} 6.0)$ differred from that with glucose which was reported at $\mathrm{pH} 5.5$ by Matsusaki et al. (1996a). Also, $\mathrm{pH} 6.5$ was the optimal $\mathrm{pH}$ for lactate production, which differred from the value $(\mathrm{pH} 6.0)$ with glucose reported by Ishizaki and Ohta (1989). Biomass and lactate were increased when the fermentation was changed from flask culture to $\mathrm{pH}$-controlled fermentation. The rate of nisin biosynthesis was faster in the $\mathrm{pH}$-controlled fermentation than in the reciprocatedflask fermentation, but the highest activity obtained was not altered.

\section{Effect of $\mathrm{CaCl}_{2}$ concentration}

Because nisin $Z$ production was increased when adding $0.1 \mathrm{M} \mathrm{CaCl}_{2}$ to the flask fermentation as previously described, the optimal concentration of $\mathrm{CaCl}_{2}$ studied was varied from $0.1 \mathrm{M}$ to $0.3 \mathrm{M}$. As a result, a high concentration of $\mathrm{CaCl}_{2}$ decreased the growth of $L$. lactis IO-1, thus, low amount of nisin $Z$ was detected. Because the buffer capacity of MOPS was less than that of $\mathrm{CaCO}_{3}$, the experimental system was then carried 

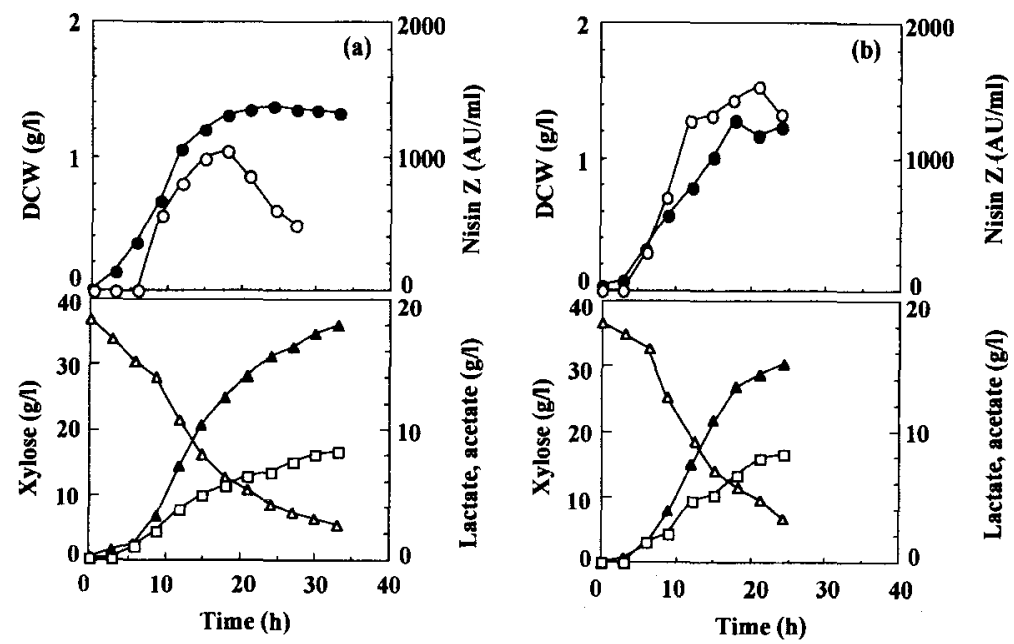

Fig. 7. Effect of $\mathrm{CaCl}$, on nisin $\mathrm{Z}$ production in $\mathrm{pH}$-controlled fermentation. The cultivation was carried out at $37^{\circ} \mathrm{C}$ and $\mathrm{pH} 6.0$ with $4 \%$ xylose without $\mathrm{CaCl}_{2}$ (a) and with $0.1 \mathrm{M} \mathrm{CaCl}_{2}$ (b).

Symbols: Cell growth $(\bigcirc)$, nisin $\mathrm{Z}(\bigcirc)$, xylose $(\Delta)$, lactate $(\mathbf{\Delta})$, acetate $(\square)$

out in pH-controlled batch fermentation. The results of the fermentation with and without $0.1 \mathrm{M} \mathrm{CaCl}_{2}$ are shown in Fig. 7. The profiles of cell growth and lactate production of the fermentation with $0.1 \mathrm{M} \mathrm{CaCl}_{2}$ were nearly the same as those without $\mathrm{CaCl}_{2}$. Specific nisin $\mathrm{Z}$ production rate was changed from $0.16 \mathrm{AU} \cdot \ell^{-1} \cdot \mathrm{h}^{-1}$ without $\mathrm{CaCl}_{2}$ to $0.28 \mathrm{AU} \cdot \ell^{-1} \cdot \mathrm{h}^{-1}$ with $0.1 \mathrm{M} \mathrm{CaCl}_{2}$. The maximum nisin $\mathrm{Z}$ activity with $\mathrm{CaCl}_{2}$ was about 1.5 times greater than without $\mathrm{CaCl}_{L}$, which reached $1520 \mathrm{AU} / \mathrm{ml}$ after $20 \mathrm{~h}$ of incubation.

\section{DISCUSSION}

Although the factors affecting the production of nisin have been studied (de Vuyst and Vandamme, 1992; Matsusaki et al., 1996a), there were no reports about xylose utilization as a carbon source. In order to make more profit on natural resources, the production of nisin $\mathrm{Z}$ from xylose was studied. From the results, nisin $\mathrm{Z}$ could be produced in xylose fermentation, as in the case of glucose fermentation (Table 1). Nisin $\mathrm{Z}$ is like other bacteriocin from lactic acid bacteria, which was proved to be a primary metabolite judging from the profiles of cell growth and nisin $Z$ poduction. It is clear that nisin $\mathrm{Z}$ was produced during the exponential cell growth phase and reached a maximum at the end of this phase or at the beginning of the stationary phase. Although maximal nisin $\mathrm{Z}$ did not correspond with maximal biomass, a critical amount of biomass seems to be a very important parameter (de Vuyst and Vandamme, 1994). Thus low specific growth rate in xylose fermentation led to low nisin $Z$ production.

In order to prolong the exponential growth phase, the initial xylose concentration was increased. The produced lactate increased with an increase in initial xylose 
concentration, whereas nisin $\mathrm{Z}$ production decreased at a xylose concentration higher than $40 \mathrm{~g} / l$ (Fig. 1). This might be responsible for the difference in the biosynthesis of these two metabolic products. Thus the biosynthesis of nisin $\mathrm{Z}$ is complicated much more than that of lactate, which is a well-known primary metabolite.

Nisin possesses an amphiphilic character with hydrophobic residues at the $\mathrm{N}$ terminus and hydrophilic ones at the C-terminus (de Vuyst and Vandamme, 1992). Yang et al. (1992) stated that, in general, bacteriocins were adsorbed on the producing cell at a $\mathrm{pH}$ near 6.0 and the desorption took place at $\mathrm{pH} 1.5$ to 2.0. The maximum and minimum adsorption with respect to $\mathrm{pH}$ slightly varied among the bacteriocins. Maximum adsorption of nisin to the producer occured at $\mathrm{pH} 6.5$, and complete loss of adsorption was found at $\mathrm{pH} 3.0$ and below. In the case of xylose fermentation, $\mathrm{pH}$ controlled at 6.0 showed the best nisin $Z$ production (Fig. 6). Because nisin $Z$ is in the class of lantibiotics which are posttranslationally modified peptides, there are many enzymes involved in transcription, translation, maturation, and transportation out of the producing cells. These enzyme activities may be affected by the $\mathrm{pH}$ of the cultivation broth.

Furthermore, addition of cation may also affect the nisin $\mathrm{Z}$ formation process. As a result, the $\mathrm{Ca}^{2+}$ ion $(0.1 \mathrm{M})$ promoted nisin Z production specifically, but not cell growth and acid production (Fig. 7). A higher than $0.1 \mathrm{M}$ concentration of calcium ion repressed the cell growth and led to low nisin $\mathrm{Z}$ production. Calcium ion may be involved in the nisin maturation process and inactivation of nisin by the producing cells (DelvesBrounghton, 1990; de Vuyst and Vandamme, 1993; Matsusaki et al., 1996a). The growth of $L$. lactis IO-1 was repressed by $50 \mathrm{mM}$ of potassium phosphate, whereas de Vuyst and Vandamme (1993) reported that inorganic phosphate stimulated both cell growth and nisin production.

Some reports stated the stimulating effect of NRSP on the growth and metabolite production of several microorganisms (Tripetchkul et al., 1992; Ishizaki, 1995a; Oiki et al., 1996 ). In this study, however, NRSP stimulated lactate production, but not production of nisin $Z$ (Figs. 3 and 4). This might be also responsible for the complex expression system for nisin $\mathrm{Z}$ compared to lactate as a well-known primary metabolite.

\section{REFERENCES}

Benkerroum, N. and W. E. Sandine 1988 Inhibitory activity of nisin against Listeria monocytogenes. J. Dairy Sci., 71: 3237-3245

Biswas, S. R., Ray, P., Johnson, M. C. and B. Ray 1991 Influence of growth conditions on the production of a bacteriocin, pediocin AcH, by Pediococcus acidilactici H. Appl. Environ. Microbiol., 57: 12651267

Delves-Brounghton, J. 1990 Nisin and its uses as a food preservative. Food Technol., 44: 100-117

De Vuyst, L. and E. J. Vandamme 1992 Influence of the carbon source on risin production in Lactococcus lactis subsp. lactis batch fermentations. J. Gen. Microbiol, 138: 571-578

De Vuyst, L. and E. J. Vandamme 1993 Influence of the phosphorus and nitrogen source on nisin production in Lactococcus lactis subsp. lactis batch fermentations using a complex medium. Appl. Microbiol. Biotechnol., 40: 12-22

De Vuyst, L. and E. J. Vandamme 1994 Nisin, a lantibiotic produced by Lactococcus lactis subsp. lactis: properties, biosynthesis, fermentation and applications. In "Bacteriocins of Lactic Acid Bacteria", ed. by L. de Vuyst and E. J. Vandamme, Blackie Academic and Professional, Glasgow, pp. 151-221

Ishizaki, A. and T. Ohta 1989 Batch culture kinetics of L-lactate fermentation employing Streptococcus sp. IO-1. J. Ferment, Bioeng, 67: 46-51 
Ishizaki, A., Osajima, K., Nakamura, K., Kimura, K., Hara, T. and T. Ezaki 1990 Biochemical characterization of Lactococcus lactis IO-1 whose optimum temperature is as high as $37^{\circ} \mathrm{C} . J$. Gen. Appl. Microbiol., 36: 1-6

Ishizaki, A., Matsusaki, H., Uryu, K., Inui, T., Kurematsu, K., Ichii, S., Hayami, T., Tonokawa, M. and Y. Koba 1992a Biochemical properties of a new lantibiotic produced by Lactococcus lactis IO-1. J. Fac. Agr., Kyushu Univ., 37: 1-11

Ishizaki, A., Ueda, T., Tanaka, K. and P. F. Stanbury 1992b L-Lactate production from xylose employing Lactococcus lactis IO-1. Biotechnol. Lett., 14: 599-604

Ishizaki, A., Ueda, T., Tanaka, K. and P. F. Stanbury 1993 The kinetics of end-product inhibition of Llactate production from xylose and glucose by Lactococcus lactis IO-1. Biotechnol. Lett., 15: 489-494

Ishizaki, A. 1995a Natural rubber serum that contains a special growth promoter for bifidobacterium. Biosci. Biotech. Biochem., 59: 1150-1151

Ishizaki, A. and T. Ueda $1995 \mathrm{~b}$ Growth kinetics and product inhibition of Lactococcus lactis IO-1 culture in xylose medium. J. Ferment. Bioeng., 80: 287-290

Matsusaki, H., Endo, N., Sonomoto, K. and A. Ishizaki 1996a Lantibiotic nisin Z fermentative production by Lactococcus lactis IO-1: relationship between production of the lantibiotic and lactate and cell growth. Appl. Microbiol. Biotechnol., 45: 36-40

Matsusaki, H., Endo, N., Sonomoto, K. and A. Ishizaki 1996b Development of purification method and identification of a peptide antibiotic produced by Lactococcus lactis IO-1. Food Sci. Technol., Int., 2 157-162

Oiki, H., Sonomoto, K. and A. Ishizaki 1996 Growth stimulating effects of natural rubber serum on Bifidobacterium bifidum. J. Ferment. Bioeng., 82: 165-167

Parente, E., Ricciardi, A. and G. Addario 1994 Influence of $\mathrm{pH}$ on growth and bacteriocin production by Lactococcus lactis subsp. lactis 140 NWC during batch fermentation. Appl. Microbiol. Biotechnol., 41: $388-394$

Tripetchkul, S., Tonokawa, M. and A. Ishizaki 1992 Ethanol production by Zymomonas mobilis using natural rubber waste as a nutritional source. J. Ferment. Bioeng., 74: 384-388

Winkowski, K., Bruno, M. E. C. and T. J. Montville 1994 Correlation of bioenergetic parameter with cell death in Listeria monocytogenes cells exposed to nisin. Appl. Environ. Microbiol., 60: 4186-4188

Yang, R., Johnson, M. C. and B. Ray 1992 Novel method to extract large amounts of bacteriocins from lactic acid bacteria. Appl. Environ. Microbiol., 50: 3355-3359 